J. Dairy Sci. 95:4735-4746

http://dx.doi.org/10.3168/jds.2012-5393

(C) American Dairy Science Association ${ }^{\circledR}, 2012$.

\title{
Invited review: Strategies for promoting productivity and health of dairy cattle by feeding nonforage fiber sources
}

\author{
B. J. Bradford ${ }^{1}$ and C. R. Mullins \\ Department of Animal Sciences and Industry, Kansas State University, Manhattan 66506
}

\begin{abstract}
High-fiber byproducts are generated by several industries, and the supplies of some of these nonforage fiber sources (NFFS) are increasing. Although NFFS generally have limited utility in nonruminant diets, dairy cattle nutritionists can use these products to partially replace both forages and concentrates in lactation diets. Research has shown that production responses vary, but under certain conditions, NFFS-based diets can maintain or improve performance of dairy cattle. Traditional dietary formulation strategies are not ideal when formulating diets to contain large concentrations of NFFS. When feeding high levels of NFFS $(\geq 15 \%$ inclusion rates, dry matter basis), less physically effective fiber is required; however, determining if this requirement has been met can be challenging, mainly because of the lack of a broadly applicable method for quantifying effective fiber in the field. Nutritionists must also be conscious of the nutrient variation that exists among many NFFS. Strategies to reduce risks associated with this variability include purchasing feed from a sole supplier who demonstrates product consistency and combining multiple NFFS at lower inclusion rates. A targeted approach whereby nonforage fiber primarily replaces some forage fiber for higher-producing cows but partially replaces some starch for lower-producing cows can optimize nutrient utilization without sacrificing animal health. In summary, the judicious use of NFFS represents an opportunity to improve the productivity and health of cattle in all stages of lactation while potentially controlling feed costs.
\end{abstract}

Key words: byproduct, lactation, physically effective fiber, formulation

\section{INTRODUCTION}

For years, dairy nutritionists have used cereal grains, oilseed meals, and forages as primary dietary ingredi-

Received January 30, 2012.

Accepted May 19, 2012.

${ }^{1}$ Corresponding author: bbradfor@ksu.edu ents of TMR. Traditionally, the majority of grains and forages have been produced on-farm, but the trend for increased cow numbers per farm has made it infeasible for many operations to maintain entirely integrated production systems, forcing many dairy producers, particularly in the western United States, to purchase feed from off-farm sources. Unfortunately, the last decade has brought increased pressure for land use, tighter commodity supplies, and higher cereal grain prices, which have resulted in significantly higher feed costs for dairies. These trends, however, have been accompanied by an increasing supply of high-fiber byproduct feeds, many derived from biofuel production. Indeed, an estimated $40 \%$ of the corn grain harvested in the United States in 2011 was utilized by the wet and dry milling industries (World Agricultural Outlook Board, 2012). This review will highlight literature related to feeding nonforage fiber sources (NFFS) with the goal of providing nutritionists with practical strategies for incorporating these feedstuffs into diets of lactating cows without compromising health or productivity.

\section{Nonforage Fiber Sources}

Around the world, many crops are processed to recover particular fractions of the plant, and in many cases, the fiber component of the crop is of little value for manufacturing. As a result, many byproducts of industrial processing are relatively high in fiber content, making them particularly suitable as feedstuffs for ruminants. Table 1 lists of some of the more common NFFS used worldwide. A survey of 28 university-affiliated dairy nutritionists in 1995 documented the utilization rates of 14 of these products in the United States, with substantial variation across different regions (Mowrey and Spain, 1999). However, there is a lack of published research evaluating many of the NFFS listed, and as a result, the focus of this review will be limited to brewers spent grains, corn gluten feed (CGF), distillers grains with solubles (DGS), soybean hulls, sugar beet pulp, and wheat middlings. Furthermore, this review will focus specifically on lactating dairy cattle diets incorporating $\geq 15 \%$ NFFS (DM basis). 
Table 1. Nonforage fiber sources ( $>30 \%$ NDF) commonly fed to dairy cattle

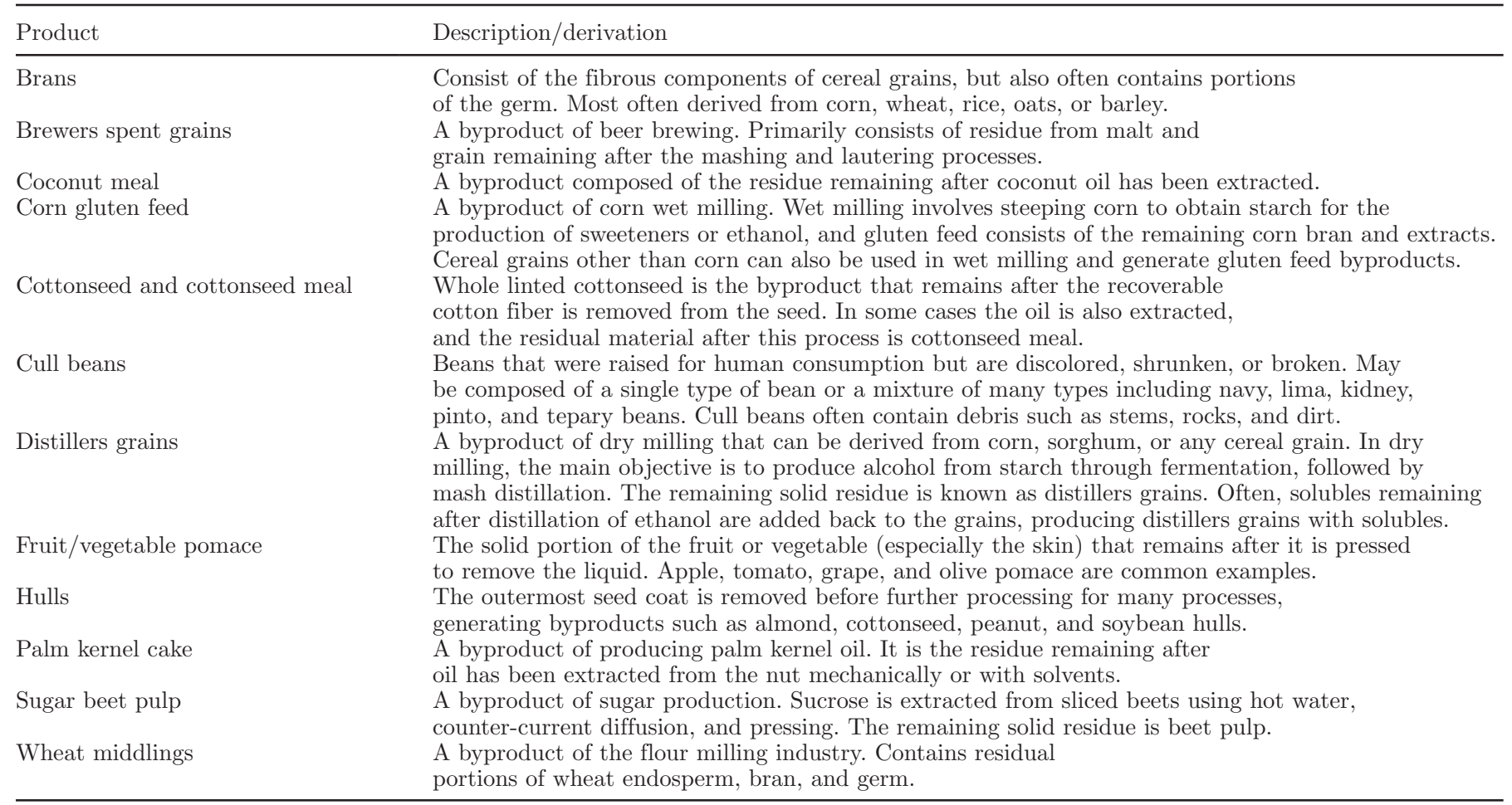

\section{Societal Impacts}

Before delving into the details of utilizing NFFS in feeding dairy cattle, it is perhaps worthwhile to consider whether this is a wise objective. Feeding byproducts to ruminants is, of course, nothing new; the first evaluation of such an ingredient in this journal was published more than 90 yr ago (McCandlish, 1920), and similar byproducts likely have been fed to ruminants for centuries.

Recent analyses have quantified some of the societal effects of utilizing NFFS in ruminant agriculture. The relative merits of growing corn for the production of ethanol have been highly controversial, not least because some analyses suggest a negative energy return to ethanol production after agronomic and processing inputs are considered (Pimentel, 2003). However, a more recent and comprehensive analysis suggests that production of corn ethanol fuel generates a modest positive energy return, with nearly all of this energy return accounted for by the feeding value of DGS for ruminant agriculture (Hill et al., 2006). Likewise, the profitability of the dry milling industry is heavily dependent on revenue from DGS sales. Although market conditions change dramatically with oil and corn prices in this industry, a 2005 analysis indicated that 20 to $30 \%$ of total sales in a dry milling operation are derived from DGS (Rajagopalan et al., 2005). The debate over the merits of the ethanol industry has led to close scrutiny and a great deal of analysis, but byproducts play an important role in many other industries as well. The estimated use of 9 NFFS by the dairy industry in California alone was over 2.5 million metric tonnes in 1992 , with a market value of over $\$ 230$ million (Grasser et al., 1995). Without the ability to feed high-fiber byproducts to ruminants, industries that supply several human food ingredients (e.g., high-fructose corn syrup, apple juice) would lose revenue from the byproduct, incur additional costs to dispose of the byproduct (Van Horn et al., 1996), or both. As a result, the use of such byproducts in ruminant agriculture improves both the environmental and economic sustainability of these industries, ultimately making their products less expensive.

Utilizing NFFS also carries advantages from the perspective of the dairy industry. At a time when the sustainability of animal agriculture is being questioned, highlighting the integral role of byproducts in feeding dairy cattle is important. VandeHaar (1998) assessed the efficiency of land use as a function of level of productivity and feeding system using a practical $32 \%$ NFFS diet as an example of a byproduct-reliant feeding system. Although this analysis assumed that more feed would be required to reach a given production level when NFFS were utilized, the total amount of land required in the byproduct-based scenario was only 
$51 \%$ of that required in the traditional TMR scenario (VandeHaar, 1998). By discounting feeds that would be waste products from a human perspective, this analysis suggested that dairy systems incorporating significant quantities of NFFS can generate a yield of nutrients for human consumption per hectare similar to corn/ soybean rotations grown for direct human consumption (VandeHaar, 1998). Regardless of the proposed societal benefits of feeding NFFS to dairy cattle, this approach is sustainable only if it also improves the profitability of dairy farms.

\section{Economics of Feeding NFFS}

One of the difficulties in feeding NFFS is in assessing their relative value compared with traditional feedstuffs. A survey of more than 500 dairy nutritionists and veterinarians conducted in 2010 indicated that 89\% used DGS (Dairy Herd Network, 2010), clearly suggesting that at least this NFFS is cost effective for use on many dairies. In general, the utility of NFFS outside of the livestock feeding industry is limited, and as a result, these feedstuffs can sometimes be purchased at a lower cost per unit of nutrients supplied than traditional ingredients.

Determining the value of NFFS is not a simple task. For many years, models have existed for quantifying the value of feeds by assigning a value to energy and $\mathrm{CP}$ based on the costs of reference feeds (Petersen, 1932). However, St-Pierre and Glamocic (2000) have discussed the shortcomings of these methods and circumvented those issues by using a multiple regression approach to generate nutrient values based on analysis of many commodity prices. The newest version of this software (Sesame III, Code Star Software LLC, Dublin, OH) takes the additional step of attempting to account for differences in forage attributes, allowing for more accurate comparisons on specific farms (St-Pierre, 2005).

Analysis of NFFS prices and values in the Ohio market over a 12-yr period (St-Pierre and Glamocic, 2000; St-Pierre and Knapp, 2008; St-Pierre, 2011) demonstrates that market prices of NFFS can deviate substantially from the value of the nutrients supplied, in both positive and negative directions. Much of this deviation between value and cost for NFFS is driven by proximity to sources of these feedstuffs, especially for wet products that are exceptionally expensive to transport (on a DM basis).

Unfortunately, no market survey can account for all of the potential costs and benefits of utilizing different ingredients in a diet. For instance, the short shelf life of some NFFS can lead to excessive feed shrink, which increases the cost of the product that is actually consumed. Drying can prevent shrink associated with spoilage, but can create a dusty product that more easily scatters, introducing another source of shrink. Many NFFS are not easily stored in upright bins, so handling costs can be higher than for concentrates. On the other hand, wet NFFS may serve as TMR binding agents, minimizing sorting and its associated nutritional problems. Such considerations can affect the true cost and value of NFFS on a particular farm.

In some scenarios, replacement of grain with NFFS can be profitable. Ranathunga et al. (2010) compared a $29 \%$ starch diet with no NFFS to a $20 \%$ starch diet including 21\% DGS and 9.6\% soybean hulls (DM basis) in place of concentrates. Given the market conditions at the time, the NFFS-based diet decreased feed costs by $\$ 1.42 /$ cow per day (29\%) and, more importantly, increased income over feed cost by the same amount (Ranathunga et al., 2010). Rezac et al. (2010) used a high-NFFS diet (46\% CGF, DM basis) to evaluate the elimination of corn silage and alfalfa from a lactation diet. This formulation strategy decreased feed costs per cow by $\$ 0.31 / \mathrm{d}$; however, income over feed cost declined for the high-NFFS diet because of decreased milk yield (Rezac et al., 2010). The profitability of feeding NFFS often depends on the local feed environment, but regardless of location, wise formulation decisions are critical for NFFS-based diets to support adequate milk production, and in turn, profitability.

\section{Formulation Strategies}

Traditionally, many nutritionists have emphasized forage:concentrate ratio as a starting point for formulating dairy cattle rations. Unfortunately, this metric is quite imprecise for meeting the nutritional needs of a lactating cow; for example, both corn silage and wheat straw are considered forages, yet they have vastly different chemical and physical properties. These problems become even more obvious when including NFFS, which are high in fiber (like forages) but are rapidly passed from the rumen (like concentrates). In recent decades, most nutritionists have shifted to relying on targeted concentrations of energy, NDF, protein, and micronutrients. Implicit in either the forage:concentrate or NDF/energy targets is the recognition that productivity of lactating cows is often limited by energy supply (Allen, 2000), yet adequate physically effective fiber is also required to maintain rumen health and milk fat yield.

When incorporating a novel ingredient into a TMR, it is tempting to directly replace an existing component of the diet. In one study, replacement of corn grain with soybean hulls increased milk fat concentration with few effects on other production parameters (Ipharraguerre et al., 2002). Gencoglu et al. (2010) also partially 
replaced corn grain with soybean hulls and observed increased FCM, in spite of a tendency for decreased feed efficiency, because of increased DMI. However, direct substitution rarely represents the optimal use of such ingredients. This is evident from other trials in which soybean hulls or beet pulp replaced corn grain and decreased uncorrected milk production (Nakamura and Owen, 1989; Pantoja et al., 1994) or milk protein production (Mansfield and Stern, 1994; Mansfield et al., 1994).

Many NFFS provide valuable nutrients in addition to digestible fiber, and most often, that nutrient is protein. Therefore, NFFS commonly replace a combination of both cereal grains and oilseed meals in rations (Armentano and Dentine, 1988; Younker et al., 1998). In scenarios where the initial diet is highly fermentable, replacement of concentrates with NFFS can improve production, particularly of milk fat (Weiss, 2012). However, replacing concentrates with NFFS in more conservative diets can sacrifice productivity because of a decrease in digestible energy supply. Although most nonforage fiber is relatively digestible compared with forage fiber (Bhatti and Firkins, 1995; Dann et al., 2007), its digestibility in vivo may be limited to some extent by its more rapid passage rate (Edionwe and Owen, 1989; Firkins, 1997). More to the point, replacing highly digestible NFC with NDF from NFFS can depress feed intake, decrease diet digestibility, or limit milk production (Staples et al., 1984; MacLeod et al., 1985; Batajoo and Shaver, 1994; Schingoethe et al., 1999; Ferraretto et al., 2011).

Recent experience with NFFS suggests that these ingredients can be utilized most effectively when traditional carbohydrate targets are abandoned and nonforage NDF is used to replace a combination of forage NDF and starch. Highly digestible NDF sources can supply substantial amounts of ruminally fermentable OM with more constant acid production compared with highstarch concentrates (Fellner and Belyea, 1991; Stock et al., 2000). Nonforage fiber sources can also replace portions of forage fiber if the physical characteristics of the ration remain sufficient to stimulate rumination (Allen and Grant, 2000).

A series of 3 experiments reported by Boddugari and colleagues (2001) demonstrates typical responses to these different approaches to NFFS utilization. First, a milling product similar to $\mathrm{CGF}$ was used to replace 0, 50,75 , or $100 \%$ of the concentrates (on a DM basis) in a lactation diet. As suggested above, this replacement of NFC with NDF decreased DMI, although milk yield was maintained in this case, resulting in improved feed efficiency (Boddugari et al., 2001). A second experiment then evaluated partial replacement of forage in addition to the complete replacement of concentrates by the milling product; these 4 diets contained 45,53 , 62 , and $70 \%$ NFFS (DM basis), with as little as $30 \%$ forage in the most extreme diet. As the NFFS inclusion rate increased in this experiment, milk production increased but without an increase in fat yield (Boddugari et al., 2001). Finally, a third study was conducted to compare a control diet to one with $40 \%$ milling product replacing portions of both the forages and concentrates. This approach to NFFS utilization resulted in a $6 \mathrm{~kg} / \mathrm{d}$ increase in FCM yield, driven by a $20 \%$ increase in production efficiency (Boddugari et al., 2001). Indeed, numerous studies indicate that optimal feeding of NFFS can improve productivity of dairy cattle (Belibasakis and Tsirgogianni, 1996; Ipharraguerre and Clark, 2003; Schingoethe et al., 2009).

\section{Energy}

Rather than focus on specific nutrients as energy sources, many nutritionists simply formulate for a target predicted energy density, but this approach has shortcomings. Model predictions of energy supply from NFFS are likely to be imprecise for several reasons. First, models on which these energy predictions are based are generally derived from data that did not include diets with high inclusion rates of NFFS. Another problem is that models do not adequately account for associative effects within diets, which is likely to be a major factor when substantial amounts of NFC are replaced by nonforage NDF (Edionwe and Owen, 1989; Beckman and Weiss, 2005; Gencoglu et al., 2010; Weiss, 2012). Finally, one common response to highNFFS diets is a change in DMI, in some cases by more than $3 \mathrm{~kg} / \mathrm{d}$ (Cunningham et al., 1993; Kononoff et al., 2006; Mullins et al., 2010). Altered DMI, which is not accounted for in models, makes energy density predictions both less accurate and less relevant. Therefore, instead of formulating for energy density or starch targets, utilization of large amounts of NFFS requires a more flexible, iterative process.

Experience suggests that the following is an effective approach to formulating diets with high NFFS inclusion rates (additional discussion follows):

(1) Determine a minimum physically effective fiber concentration to maintain rumen health and milk fat yield. Include forages necessary to meet this requirement, including a safety margin to allow for variations in mixing, forage composition, or both.

(2) Incorporate a combination of NFFS and concentrates to provide at least $34 \% \mathrm{NFC}$, letting total NDF increase with increasing NFFS incorporation. 
(3) Evaluate ruminally available unsaturated FA supply and adjust inclusion rates to limit the risk of milk fat depression (Lock, 2010).

(4) Evaluate protein supply, including rumenundegraded protein, metabolizable lysine, and metabolizable methionine supply predictions. Adjust ingredient proportions or add bypass AA sources to balance protein supplies.

(5) Re-evaluate targets for steps 1 through 3, and then balance for micronutrients.

Using this approach, NDF concentrations may be much higher than in a typical diet, yet because of the relatively high digestibility of many sources of nonforage NDF, such diets can provide adequate ruminally fermentable OM to support high production of microbial protein and VFA (Hristov, 2006), and, in turn, milk yield (Dann and Grant, 2009). Diets that incorporate more than 20\% NFFS (DM basis) can support milk yields in excess of $50 \mathrm{~kg} / \mathrm{d}$ with less than $22 \%$ starch and as much as 37\% NDF (Boguhn et al., 2010; Gencoglu et al., 2010; Ferraretto et al., 2011). Many other NFFS-based diets have supported production levels above $35 \mathrm{~kg} / \mathrm{d}$ with just 25 to $36 \%$ NFC (Batajoo and Shaver, 1994; Boddugari et al., 2001; VanBaale et al., 2001; Miron et al., 2003; Voelker and Allen, 2003; Kononoff et al., 2006; Ranathunga et al., 2010).

One significant difference in this approach is that sources of fat will not be formulated into diets because of the lack of focus on predicted energy density; however, this difference does not negate the utility of dietary fat in some NFFS-based rations. In cases where the ruminal acid load is already high but more energy is needed to support milk production, adding fat can be a useful way to provide additional energy. In one study, cows fed high-NFFS diets in early lactation outperformed cows fed a traditional diet, but the addition of $2.25 \%$ hydrogenated FA further improved productivity (Weiss and Pinos-Rodriguez, 2009).

Research on the effects of fat source within NFFSbased diets is very limited. Pantoja et al. (1994) evaluated the effect of fat saturation on digestibility and production responses to a diet including $20 \%$ soybean hulls. Diets included saturated tallow, tallow, or an animal-vegetable fat blend at relatively high concentrations, providing a mean dietary FA concentration of $6.1 \%$ of DM. In this scenario, increasing the proportion of dietary unsaturated FA linearly decreased DMI, quadratically decreased microbial CP flow, and tended to linearly decrease milk fat content and yield (Pantoja et al., 1994). Despite the low starch concentrations in these diets, ruminally available unsaturated FA nevertheless induced milk fat depression and ap- peared to impair ruminal fermentation. Inclusion of a fat source may allow for further decreases in NFC content of NFFS-based diets, with possible improvements in productivity, but the supply of ruminally available unsaturated FA should be limited to prevent negative effects on ruminal fermentation and biohydrogenation (Lock, 2010).

\section{Physically Effective Fiber}

Even though forage:concentrate ratio has little utility, the physical characteristics of the TMR cannot be ignored. Physical characteristics of the TMR have a major effect on ruminal retention and chewing activity, which affect rumen health, DMI, diet digestibility, and milk fat production (Allen and Grant, 2000). Substituting NFFS for grain will likely have a minimal effect on particle size, but substitution for forage can greatly reduce the mean particle size of the diet. For this reason, nutritionists need to consider physically effective NDF (peNDF) when formulating diets.

Physically effective NDF can be calculated in multiple ways, but accepted definitions account for the ability to stimulate chewing, the ability to maintain milk fat concentration and production, or both (Grant, 1997). Thus, peNDF combines information on particle length and chemical content of the diet. Nonforage fiber sources have a small mean particle size and are typically low in lignin and high in digestible fiber, so replacing forages with NFFS will decrease the physical effectiveness of NDF. This can improve energy supplied by the diet (Yang and Beauchemin, 2006), especially if ruminal distention is restricting DMI (Allen, 2000; Zebeli et al., 2010), as long as the level of fermentable carbohydrate does not exceed the rumen's capacity for neutralization and outflow of VFA.

Despite the theoretical value of peNDF, a fieldapplicable method for estimating peNDF of a diet has remained elusive. One meta-analysis (Zebeli et al., 2008) demonstrated reasonably strong associations between $\mathrm{peNDF}_{>1.18}$, ruminal $\mathrm{pH}$, and milk fat yield. The peNDF $>1.18$ variable is derived by determining the proportion of TMR particles retained on a $1.18-\mathrm{mm}$ screen and multiplying by the total NDF concentration of the diet (Mertens, 1997). Although the metaanalysis suggested that $\mathrm{peNDF}_{>1.18}$ is a valuable metric for typical dairy TMR, the database used to evaluate it was not focused on high-NFFS diets. In fact, the mean concentration of NDF from forage in the database was $21.9 \%$ of DM (Zebeli et al., 2008), and NFFS-based diets can contain as little as $12 \% \mathrm{NDF}$ from forage (Harvatine et al., 2002; Miron et al., 2003; Mullins et al., 2010). With such a small proportion of NDF com- 
ing from forage sources, using total dietary NDF as a factor in peNDF $>1.18$ calculations is unlikely to result in a useful metric for NFFS-based diets.

A comparison of recent results with low and high NFFS inclusion rates demonstrates this point. Yang and Beauchemin (2007) used primarily traditional forages and concentrates at different proportions and cut lengths to generate diets with a range of peNDF values. One finding from the study was that $\mathrm{peNDF}_{>8.0}$ (the proportion of particles retained by a $8-\mathrm{mm}$ sieve multiplied by dietary NDF content) was a much better predictor of ruminal $\mathrm{pH}$ dynamics than $\mathrm{peNDF}_{>1.18}$ (Yang and Beauchemin, 2007); however, despite having one diet with a peNDF $>8.0$ of just $9.6 \%$ of DM, milk fat yield was maintained across all treatments. In contrast, another recent study evaluated 3 diets with CGF inclusion rates ranging from 33 to $56 \%$ of DM, with concentrations of NDF from forage decreasing from 15.3 to 9.3\% of DM (Rezac et al., 2012). Although peNDF $>8.0$ concentrations in these diets remained above $10.7 \%$ of $\mathrm{DM}$, the lowest forage diet decreased milk fat yield by almost $20 \%$ and caused clinical acidosis. In this experiment, $\mathrm{peNDF}_{>1.18}$ values were even less predictive; peNDF $_{>1.18}$ was greater in the diet that induced milk fat depression than in the control diet (Rezac et al., 2012). Based on these comparisons, peNDF thresholds determined to be safe in traditional rations may not apply to high-NFFS diets. In these examples, milk fat was maintained when NDF from forage was $16.0 \%$ of DM (Yang and Beauchemin, 2007) or $12.9 \%$ of DM, but not when it decreased to $9.3 \%$ of DM (Rezac et al., 2012), suggesting that forage NDF should not be ignored in NFFS-based diets.

Unfortunately, no single tool can quantify fiber adequacy in dairy rations and uniformly predict rumen health responses to diets. For NFFS-based diets, we advocate an approach similar to that proposed by NRC (2001), which uses a sliding scale of NDF from forage and total NDF concentrations (Figure 1). For example, a minimum of $18 \%$ NDF from forage is recommended if total NDF content of the diet is just $27 \%$, but only $15 \%$ NDF from forage is considered necessary if total NDF is $33 \%$ of DM (NRC, 2001). This approach has been successfully extended to 12 to $13 \%$ NDF from forage with 31 to $35 \%$ total NDF without inducing milk fat depression (Miron et al., 2003; Mullins et al., 2010; Rezac et al., 2012). The tradeoffs between forage and total NDF reflect the concept that nonforage NDF is approximately half as effective as forage NDF at maintaining ruminal function and milk fat yield (Swain and Armentano, 1994). If these guidelines are followed and diets are prepared such that $<65 \%$ of particles (by weight) pass through an 8 -mm sieve (Kononoff et al., 2003), then NFFS diets should support normal rumen

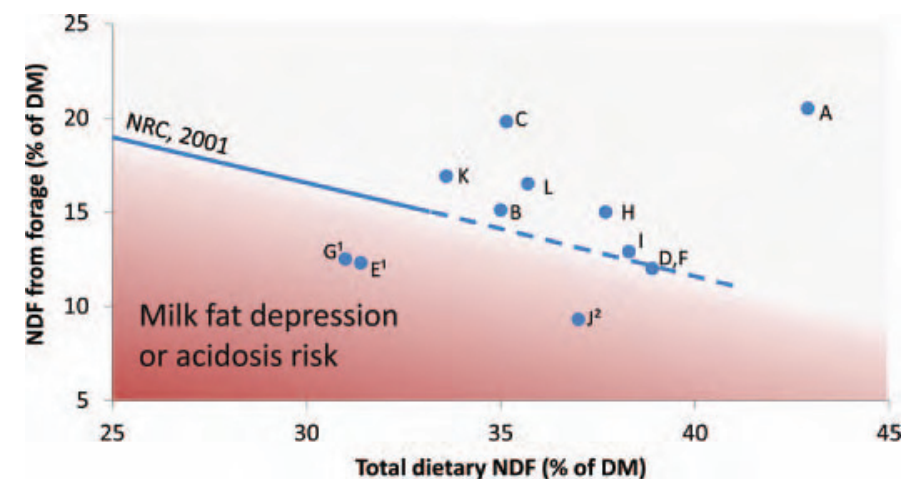

Figure 1. Dietary NDF and forage NDF concentrations of nonforage fiber source (NFFS) diets. Diets $(\mathrm{n}=12$ ) incorporating $\geq 15 \%$ NFFS (DM basis) were compared with control diets in 11 published studies. Comparisons chosen here used NFFS to replace at least some forage in diets for lactating dairy cattle. Diets that decreased ruminal $\mathrm{pH}$ (1) or induced milk fat depression (2; decreased both milk fat content and yield) are denoted with superscripts; other diets had no significant effect on these variables compared with more traditional control diets. Dietary NDF concentrations of control diets ranged from 28 to $39 \%$ of DM. The solid line represents the minimum combination of NDF and NDF from forage recommended by NRC (2001), and the dashed line represents a linear extension of that minimum recommendation. This simple regression represents the concept that nonforage NDF is approximately $50 \%$ as effective as forage NDF in maintaining rumen function. A = Batajoo and Shaver (1994; brewers grains, wheat middlings, and soybean hulls); $\mathrm{B}=$ Boddugari et al. (2001; 40\% corn milling product); $\mathrm{C}=$ Ferraretto et al. (2011; wheat middlings and distillers grains with solubles); D = Halachmi et al. (2004; soybean hulls); $\mathrm{E}=$ Harvatine et al. (2002; whole cottonseed, soybean hulls, and cottonseed hulls); F = Miron et al. (2003; soybean hulls); G = Mullins et al. (2010; corn gluten feed); $\mathrm{H}=$ Pantoja et al. (1994; soybean hulls); I = Rezac et al. (2012; 46\% corn gluten feed); J = Rezac et al. (2012; 56\% corn gluten feed); K = Weiss and Pinos-Rodriguez (2009; soybean hulls, wheat middlings, and distillers grains with solubles); L $=$ Younker et al. (1998; brewers grains). Color version available in the online PDF.

function. Some wet NFFS can be advantageous for meeting this fiber requirement because they tend to bind diet components together and prevent cows from sorting against longer forage particles (Sullivan et al., 2011).

Despite the importance of effective fiber for dairy cattle, we cannot forget that milk fat depression is a multifactorial problem. For example, ruminally degradable starch supply may be an independent risk factor for both decreased ruminal $\mathrm{pH}$ (Zebeli et al., 2008) and milk fat depression (Maia et al., 2009; Weiss, 2012). In fact, one of the key reasons it is safe to feed high levels of NFFS in low-forage diets is that such diets are typically quite low in starch; diets as low as 12 to $14 \%$ starch have been used in experimental settings (Mahjoubi et al., 2009; Rezac et al., 2012). Second, degradability of the forage NDF fraction must be considered as well. Even if recommended forage NDF concentrations are met, NFFS-based diets with very degradable forage NDF (i.e., from brown midrib corn silage) can 
still result in milk fat depression (Holt et al., 2010). Finally, some NFFS, especially DGS, can provide a substantial load of rumen-available unsaturated FA, which is another key risk factor that promotes milk fat depression (Hippen et al., 2010). All of these factors must be considered to formulate a diet that will support acceptable component production.

\section{Protein}

Use of NFFS can have a significant effect on protein fractions in a diet. Some NFFS, such as CGF, provide a highly degradable source of protein, whereas others, such as DGS, provide more RUP, especially if a dried product is fed (Kononoff et al., 2007). These factors can have a considerable effect on diet formulation. For example, if rumen-undegraded protein from corn DGS is used to displace a bypass soybean meal product (thereby attempting to maintain MP supply), the AA composition of MP can shift such that the first-limiting AA changes from methionine to lysine. Two analyses of 8 NFFS derived from corn found that all had RUP fractions with $\leq 3.5 \%$ lysine (\% of total AA; Kelzer et al., 2010; Mjoun et al., 2010), substantially less than the recommended target of $7.2 \%$ lysine in MP (NRC, 2001). In this situation, supplementing with a source of the appropriate first-limiting AA can support increased milk protein production (Nichols et al., 1998). Although model predictions of metabolizable AA supply are likely imprecise for high-NFFS diets (Mullins et al., 2011; Pacheco et al., 2012), nutritionists should nonetheless consider adjusting sources of bypass protein if predicted supplies of methionine and lysine vary considerably from requirements.

Another factor worthy of consideration in balancing NFFS diets for protein content is the digestibility of protein, especially from dried sources. Survey information on digestibility of NFFS is limited. However, Kleinschmit et al. (2007) analyzed 6 commercial DGS products using a 2-step procedure (ruminal incubation followed by pepsin and pancreatin digestion) to estimate both RUP supply and digestibility. Estimated total-tract CP digestibility ranged from $85.3 \%$ to as low as $70.7 \%$, and all DGS products had significantly lower estimated CP digestibility than soybean meal (Kleinschmit et al., 2007). Three of the dried DGS products had digestibility estimates equivalent to the wet DGS product evaluated, but 2 others were significantly less digestible, suggesting that drying does not necessarily impair protein digestibility, but it might if the process if not carefully controlled.

Is it worthwhile for a nutritionist to attempt to predict the digestibility of CP in NFFS from a given source plant? Many questions have been raised in the literature about utility of the ADIN assay, which traditionally has been used to quantify the presence of indigestible Maillard reaction products in feeds. Several studies have suggested that ADIN content in DGS does not accurately predict protein digestibility (Ham et al., 1994; Nakamura et al., 1994; Kelzer et al., 2010), with wide differences in ADIN concentrations resulting in only very small alterations in estimated total-tract $\mathrm{CP}$ digestibility. Based on such findings, there is likely little reason to attempt to quantify ADIN in DGS samples on a regular basis, although having a mean estimate of ADIN over time from different source plants may still be useful.

\section{LIMITATIONS AND PRACTICAL CONCERNS}

Despite vast differences in the nutrient profiles across individual NFFS, similar nutritional concepts need to be considered as nutritionists incorporate these ingredients into diets. The first thing to consider when incorporating a novel ingredient is the derivation of the feedstuff. Because some byproducts are treated like a waste stream during industrial processing, antinutritional factors can easily be introduced. Nutritionists should therefore be knowledgeable of the derivation process to aid in monitoring for potential problems.

\section{Variability}

The chemical and physical composition of feedstuffs can vary dramatically across batches. For example, the NRC (2001) reported high standard deviations for the $\mathrm{CP}(23.8 \pm 5.7 \%$ of DM) and $\mathrm{NDF}(35.5 \pm 6.8 \%$ of DM) concentrations of CGF. In a Canadian study, Droppo et al. (1985) tested the DM and nutrient composition of 4 samples from each of 14 truckloads of CGF that had been delivered from a single starch plant. Although the range of DM values was wide (40 to $48 \%$ ), more concerning was the variability of $\mathrm{CP}$ and mineral concentrations between loads; the CV ranged from 12 to $35 \%$. Not surprisingly, similar variability has been observed across suppliers for other NFFS (Kleinschmit et al., 2007). The variation in nutrient content likely reflects differences in sources of processing material or in the processing technique for particular batches. Thus, nutritionists must be cognizant of this variation when incorporating these ingredients into diets.

The risks associated with variable ingredient composition can be mitigated (St-Pierre and Weiss, 2006). One approach is to work with a sole supplier who can demonstrate superior product consistency. Although such products often command a premium price, the resulting consistency in the TMR may make the added cost worthwhile. Another common strategy is to mini- 
mize the risk associated with any individual ingredient by using a mix of different NFFS sources. For example, Batajoo and Shaver (1994) fed a diet containing 28\% NFFS, but this was supplied by 4 different ingredients. The appropriate strategy for a given dairy depends largely on the number and types of NFFS that are cost effective to purchase in the local area, as well as on the size of the dairy (see below).

\section{Stability}

One factor that restricts the value of low-inclusionrate NFFS on small dairies is the limited stability of wet feedstuffs. Given that a dairy often needs to accept delivery of a full load of feed to acquire it at a reasonable cost, the farm needs to be able to utilize that load within 4 to $10 \mathrm{~d}$, especially in warm climates. To increase shelf life, most NFFS can be dried, but this typically adds substantial cost and largely negates the value of being in close proximity to a source plant. In addition, wet products may be more digestible and support greater productivity in some cases (Anderson et al., 2006).

Although dry products are often the best option for maintaining product stability, other feed preservation strategies exist. For example, ensiling CGF in a plastic silo bag sustained its quality, as determined by $\mathrm{pH}$, temperature, and organic acid concentrations (Jaster et al., 1984); however, the small particle size of wet NFFS can cause bags to stretch and tear, and the poor flowability of these products can cause problems for upright silos. A potential solution is to blend the NFFS with some other forage and ensile the mixture (Schroeder, 2010). Another approach to preserving wet NFFS is to apply an antimicrobial agent such as propionic acid, which has been successful for short-term preservation (Geetha et al., 2009).

\section{Minerals}

Byproducts can contain atypically high concentrations of minerals, usually because the mineral is concentrated as the most valuable fractions of a plant material are removed or because industrial processing adds a mineral that ends up in the byproduct stream. For example, DGS is often affected by both factors (Spiehs and Varel, 2009); it is quite high in phosphorus $(\approx 0.9 \%)$ due to the abundant phosphorus in corn and sorghum grain, and it is often high in sulfur (0.5 to 0.9\%, Anderson et al., 2006; Kelzer et al., 2010), not only because it is concentrated during dry milling, but also because of the use of sulfuric acid in many ethanol plants.
Elevated feed mineral concentrations increase the risk of a dietary mineral imbalance, which can affect intake and performance (Kincaid, 2000). If intake is not depressed, consumption of minerals in excess of the animal's requirements results in the great majority of the excess being excreted. This can be a significant environmental problem if manure is applied to cropland without consideration of nutrient management (Van Horn et al., 1996). In this regard, $\mathrm{P}$ has received a lot of attention. Phosphorus is essential for maintenance, growth, pregnancy, and lactation; the NRC (2001) has attempted to model these influences and estimates total $\mathrm{P}$ requirements at 0.32 to $0.38 \%$ of diet DM. In the past, many nutritionists have targeted higher $\mathrm{P}$ concentrations because of perceptions that higher P levels are necessary for optimal reproductive performance, but controlled studies have not supported this perception (Lopez et al., 2004). Nonetheless, diets that incorporate large amounts of certain NFFS (e.g., corn byproducts, wheat middlings) can exceed the $\mathrm{P}$ requirement of lactating cows even without the addition of inorganic P sources (Stewart et al., 2012). In such cases, careful nutrient management planning is essential for environmentally responsible utilization of such strategies (Van Horn et al., 1996).

In addition to causing diminished performance or excessive excretion, mineral imbalances can sometimes be detrimental to animal health. Feeding $\mathrm{P}$ to late gestation cows at a rate greater than $80 \mathrm{~g} / \mathrm{d}$ slows renal production of 1,25-dihydroxycholecalciferol (Kichura et al., 1982), increasing the risk of milk fever. Excess sulfur creates a concern for polioencephalomalacia, but this is less likely to occur in dairy cattle compared with feedlot and grazing beef animals (NRC, 2005). Excess sulfur intake has also been associated with decreased rumen motility (Bird, 1972), decreased bioavailability of $\mathrm{Cu}$ and Se (NRC, 2001), and thiamine deficiency (Gooneratne et al., 1989), although controlled research on these topics in dairy cattle is limited.

The maximum tolerable levels of many minerals have been discussed elsewhere (NRC, 2005; Weiss, 2008), and such resources should be consulted if utilization of NFFS would result in substantially elevated dietary concentrations of any mineral. Given that most dairies apply manure to cropland, nutrient management planning should be considered if the feeding strategy will greatly increase the nutrient load that must be dispersed. Therefore, considerable care must be given to mineral balance when formulating diets with NFFS, and in certain situations, excess minerals may make an otherwise profitable NFFS utilization scheme unprofitable. 


\section{TARGETING NFFS TO COWS IN DIFFERENT STAGES OF PRODUCTION}

Dairy nutrition strategies typically focus on group responses to diets. This is a logical approach given that feeding individual cows is impractical on most farms. However, recognizing the dramatic differences between individual cows is important; some cows produce 2 or 3 times more milk than other cows on a farm. Although the higher-producing cows obviously have higher requirements for nutrients than lower-producing cows, other differences also influence how cows respond to diets. Thus, it is relevant to outline strategies to improve cow nutrition and NFFS utilization through targeted feeding programs.

\section{Promoting Energy Intake in Early and Peak Lactation}

Among the highest-producing cows, especially those in early lactation, energy intake is often the primary limit to productivity (Allen et al., 2009). Cows with excellent genetics that consume high-forage diets are physically unable to consume enough energy to meet their genetic potential to produce milk (Weiss and Pinos-Rodriguez, 2009). Even when fed a typical dairy TMR, feed intake of these high producers is limited by the capacity of the gut to hold digesta (Allen, 2000). Replacing forage with NFFS often increases energy density (not only per unit of mass, but also per unit of volume) and allows for greater DMI if the cow's intake was previously limited by ruminal distention (Kononoff et al., 2006; Zebeli et al., 2010). This suggests that high-producing cows will respond positively to replacement of some forage with NFFS. If the high-producing cows can be fed in a targeted manner, a diet with just 12 to $14 \%$ NDF from forage and 35 to $40 \%$ NFC can be formulated to promote increased energy intake and productivity while using low-cost ingredients, although the high protein requirements of these cows should also be considered when evaluating NFFS for inclusion.

Experienced dairy nutritionists may wonder about the safety of feeding such fermentable diets to highproducing cows. In a study comparing responses to lowforage diets including dry ground corn or high-moisture corn grain, the more fermentable high-moisture corn diet decreased milk fat content, as expected (Bradford and Allen, 2004). The interesting part was that the highest-producing cows on the study (over $45 \mathrm{~kg}$ of milk/d) had higher milk fat content when fed the more fermentable diet, in stark contrast to milk fat depression of up to $1 \%$ (i.e., from 3.5 to $2.5 \%$ fat) in the lowest producers $(28 \mathrm{~kg} / \mathrm{d})$. The resistance to milk fat depression in high-producing cows was due to an improved capacity for biohydrogenation of FA in the rumen and decreased delivery of milk-fat-depressing FA to the mammary gland. This suggests that readily fermentable NFFS can safely replace some forage (increasing ruminally fermentable OM supply) if targeted toward high-producing cows.

\section{Promoting Metabolic Health in Late Lactation}

The lesser demand for nutrients in lower-producing cows results in some important metabolic differences. To begin with, milk production is typically not limited by nutrient availability in late lactation, but rather by the capacity of the mammary gland for milk synthesis (Capuco et al., 2003). As a result, feeding low-producing cows a nutrient-dense diet has 2 important effects: it makes more nutrients available for body weight gain and it triggers sensory mechanisms in the body to decrease feed intake. Feed intake of lower-producing cows is often limited by absorbed nutrients and not by gut fill (Allen et al., 2009). Higher-fiber diets do not dramatically depress feed intake of late-lactation cows, meaning that such diets can maintain milk production while decreasing the risk of excessive body weight gain. Therefore, diets higher in fiber can benefit late-lactation cows both by decreasing the risk of acidosis and by helping prevent the host of metabolic problems collectively known as fat cow syndrome (Morrow, 1976).

The use of NFFS primarily to replace cereal grains rather than forages in late-lactation diets can help avoid problems with excessive weight gain and depressed DMI. One example of a successful application of this approach was the replacement of barley grain with beet pulp (Mahjoubi et al., 2009). Including beet pulp at up to $17 \%$ of diet DM decreased plasma insulin concentrations and prevented an increase in body condition of late-lactation cows. Most impressively, this diet, despite providing only $12 \%$ starch, tended to increase milk energy output compared with the diet utilizing more barley grain.

Whole-herd utilization of NFFS is often limited by risk aversion in replacement of forages (a desire to maintain $>15 \%$ NDF from forage) and by concern about decreasing energy density if too much NFFS is used to replace grains. By feeding 2 or more lactation diets, dairies can fine-tune the use of NFFS for both high and low producers, allowing for higher NFFS inclusion rates in both groups. This can be an especially valuable strategy for small farms that struggle to utilize sufficient product to avoid spoilage. Most importantly, this approach allows nutritionists to capture the maximal production benefits of NFFS-based diets in peaklactation cows without risking the metabolic health of cows in later lactation. 


\section{CONCLUSIONS}

The importance of NFFS in dairy nutrition will likely continue to grow, and this review outlines a general approach for incorporating them into lactation diets. Feeding high-fiber byproducts offers potential benefits for individual dairy cows, as well as society at large, but these benefits are dependent on careful diet formulation. When incorporating NFFS into the diet, traditional carbohydrate targets should be abandoned and NFFS should typically replace portions of both forage NDF and starch. When NFFS replace forage, DMI often increases but physical effectiveness of the diet decreases, which can increase susceptibility to milk fat depression. Although physical effectiveness of fiber must be considered, no single metric has proven to consistently predict milk fat or rumen $\mathrm{pH}$ responses to diets, especially those heavily reliant on nonforage NDF. At a minimum, evaluation of dietary NDF, NDF from forage, particle size, and fat is necessary to assess the risk of acidosis, milk fat depression, or both. Cows are likely to respond differently to NFFS substitution depending on stage of lactation and level of production. Using NFFS in place of feeds with slow passage rates can allow for greater DMI if the cow's intake was previously limited by ruminal distention, as is often the case in peak lactation. In contrast, NFFS can decrease dietary energy density when used to replace concentrates, which can be useful for limiting energy intake in later-lactation cows. Overall, NFFS present opportunities to reduce feed costs, maintain or improve performance and health of dairy cattle, and increase the sustainability of the dairy industry.

\section{REFERENCES}

Allen, D. M., and R. J. Grant. 2000. Interactions between forage and wet corn gluten feed as sources of fiber in diets for lactating dairy cows. J. Dairy Sci. 83:322-331.

Allen, M. S. 2000. Effects of diet on short-term regulation of feed intake by lactating dairy cattle. J. Dairy Sci. 83:1598-1624.

Allen, M. S., B. J. Bradford, and M. Oba. 2009. Board-invited review: The hepatic oxidation theory of the control of feed intake and its application to ruminants. J. Anim. Sci. 87:3317-3334.

Anderson, J. L., D. J. Schingoethe, K. F. Kalscheur, and A. R. Hippen. 2006. Evaluation of dried and wet distillers grains included at two concentrations in the diets of lactating dairy cows. J. Dairy Sci. 89:3133-3142.

Armentano, L. E., and M. R. Dentine. 1988. Wet corn gluten feed as a supplement for lactating dairy cattle and growing heifers. J. Dairy Sci. 71:990-995.

Batajoo, K. K., and R. D. Shaver. 1994. Impact of nonfiber carbohydrate on intake, digestion, and milk production by dairy cows. J. Dairy Sci. 77:1580-1588.

Beckman, J. L., and W. P. Weiss. 2005. Nutrient digestibility of diets with different fiber to starch ratios when fed to lactating dairy cows. J. Dairy Sci. 88:1015-1023.

Belibasakis, N. G., and D. Tsirgogianni. 1996. Effects of wet brewers grains on milk yield, milk composition and blood components of dairy cows in hot weather. Anim. Feed Sci. Technol. 57:175-181.
Bhatti, S. A., and J. L. Firkins. 1995. Kinetics of hydration and functional specific gravity of fibrous feed by-products. J. Anim. Sci. 73:1449-1458.

Bird, P. 1972. Sulphur metabolism and excretion studies in ruminants. X. Sulphide toxicity in sheep. Aust. J. Biol. Sci. 25:1087-1098.

Boddugari, K., R. J. Grant, R. Stock, and M. Lewis. 2001. Maximal replacement of forage and concentrate with a new wet corn milling product for lactating dairy cows. J. Dairy Sci. 84:873-884.

Boguhn, J., H. Kluth, M. Bulang, T. Engelhard, and M. Rodehutscord. 2010. Effects of pressed beet pulp silage inclusion in maize-based rations on performance of high-yielding dairy cows and parameters of rumen fermentation. Animal 4:30-39.

Bradford, B. J., and M. S. Allen. 2004. Milk fat responses to a change in diet fermentability vary by production level in dairy cattle. J. Dairy Sci. 87:3800-3807.

Capuco, A. V., S. E. Ellis, S. A. Hale, E. Long, R. A. Erdman, X. Zhao, and M. J. Paape. 2003. Lactation persistency: Insights from mammary cell proliferation studies. J. Anim. Sci. 81:18-31.

Cunningham, K. D., M. J. Cecava, and T. R. Johnson. 1993. Nutrient digestion, nitrogen, and amino acid flows in lactating cows fed soybean hulls in place of forage or concentrate. J. Dairy Sci. 76:3523-3535.

Dairy Herd Network. 2010. Amino acid balancing survey. Accessed Apr. 10, 2012. http://images.vancepublishing.com/pdfs/dairyherd/Amino_Acid_Balancing_Survey_June_2010.pdf.

Dann, H. M., M. P. Carter, K. W. Cotanch, C. S. Ballard, T. Takano, and R. J. Grant. 2007. Effect of partial replacement of forage neutral detergent fiber with by-product neutral detergent fiber in close-up diets on periparturient performance of dairy cows. J. Dairy Sci. 90:1789-1801.

Dann, H. M., and R. J. Grant. 2009. Feeding low starch diets. Pages 143-157 in Proc. Tri-State Dairy Nutr. Conf., Ft. Wayne, IN. The Ohio State University, Columbus.

Droppo, T. E., G. K. MacLeod, and D. G. Grieve. 1985. Composition and storage characteristics of wet corn gluten feed. Can. J. Anim. Sci. $65: 265-268$

Edionwe, A. O., and F. G. Owen. 1989. Relation of intake to digestibility of diets containing soyhulls and distillers dried grains. J. Dairy Sci. 72:1786-1792.

Fellner, V., and R. L. Belyea. 1991. Maximizing gluten feed in corn silage diets for dairy cows. J. Dairy Sci. 74:996-1005.

Ferraretto, L. F., R. D. Shaver, M. Espineira, H. Gencoglu, and S. J. Bertics. 2011. Influence of a reduced-starch diet with or without exogenous amylase on lactation performance by dairy cows. J. Dairy Sci. 94:1490-1499.

Firkins, J. L. 1997. Effects of feeding nonforage fiber sources on site of fiber digestion. J. Dairy Sci. 80:1426-1437.

Geetha, P., C. Valli, and V. Balakrishnan. 2009. Evolving effective preservation technique for distiller's grain. Tamilnadu J. Vet. Anim. Sci. 5:186-193.

Gencoglu, H., R. D. Shaver, W. Steinberg, J. Ensink, L. F. Ferraretto, S. J. Bertics, J. C. Lopes, and M. S. Akins. 2010. Effect of feeding a reduced-starch diet with or without amylase addition on lactation performance in dairy cows. J. Dairy Sci. 93:723-732.

Gooneratne, S. R., A. A. Olkowski, R. G. Klemmer, G. A. Kessler, and D. A. Christensen. 1989. High sulfur related thiamine deficiency in cattle: A field study. Can. Vet. J. 30:139-146.

Grant, R. J. 1997. Interactions among forages and nonforage fiber sources. J. Dairy Sci. 80:1438-1446.

Grasser, L. A., J. G. Fadel, I. Garnett, and E. J. Depeters. 1995. Quantity and economic importance of nine selected by-products used in California dairy rations. J. Dairy Sci. 78:962-971.

Halachmi, I., E. Maltz, N. Livshin, A. Antler, D. Ben-Ghedalia, and J. Miron. 2004. Effects of replacing roughage with soy hulls on feeding behavior and milk production of dairy cows under hot weather conditions. J. Dairy Sci. 87:2230-2238.

Ham, G. A., R. A. Stock, T. J. Klopfenstein, E. M. Larson, D. H. Shain, and R. P. Huffman. 1994. Wet corn distillers byproducts compared with dried corn distillers grains with solubles as a source of protein and energy for ruminants. J. Anim. Sci. $72: 3246-3257$. 
Harvatine, D. I., J. L. Firkins, and M. L. Eastridge. 2002. Whole linted cottonseed as a forage substitute fed with ground or steam-flaked corn: Digestibility and performance. J. Dairy Sci. 85:1976-1987.

Hill, J., E. Nelson, D. Tilman, S. Polasky, and D. Tiffany. 2006. Environmental, economic, and energetic costs and benefits of biodiesel and ethanol biofuels. Proc. Natl. Acad. Sci. USA 103:1120611210.

Hippen, A. R., D. J. Schingoethe, K. F. Kalscheur, P. L. Linke, D. R. Rennich, M. M. Abdelqader, and I. Yoon. 2010. Saccharomyces cerevisiae fermentation product in dairy cow diets containing dried distillers grains plus solubles. J. Dairy Sci. 93:2661-2669.

Holt, M. S., C. M. Williams, C. M. Dschaak, J. S. Eun, and A. J. Young. 2010. Effects of corn silage hybrids and dietary nonforage fiber sources on feed intake, digestibility, ruminal fermentation, and productive performance of lactating Holstein dairy cows. J. Dairy Sci. 93:5397-5407.

Hristov, A. N. 2006. Carbohydrate effects on the efficiency of utilization of ruminal ammonia nitrogen for milk protein synthesis in dairy cows. Pages 109-139 in Trends in Dietary Carbohydrates Research. M. V. Landow, ed. Nova Publishers, New York, NY.

Ipharraguerre, I. R., and J. H. Clark. 2003. Soyhulls as an alternative feed for lactating dairy cows: A review. J. Dairy Sci. 86:10521073.

Ipharraguerre, I. R., R. R. Ipharraguerre, and J. H. Clark. 2002. Performance of lactating dairy cows fed varying amounts of soyhulls as a replacement for corn grain. J. Dairy Sci. 85:2905-2912.

Jaster, E. H., C. R. Staples, G. C. McCoy, and C. L. Davis. 1984. Evaluation of wet corn gluten feed, oatlage, sorghum-soybean silage, and alfalfa haylage for dairy heifers. J. Dairy Sci. 67:1976-1982.

Kelzer, J. M., P. J. Kononoff, L. O. Tedeschi, T. C. Jenkins, K. Karges, and M. L. Gibson. 2010. Evaluation of protein fractionation and ruminal and intestinal digestibility of corn milling co-products. J. Dairy Sci. 93:2803-2815.

Kichura, T. S., R. L. Horst, D. C. Beitz, and E. T. Littledike. 1982. Relationships between prepartal dietary calcium and phosphorus, vitamin $\mathrm{D}$ metabolism, and parturient paresis in dairy cows. J. Nutr. 112:480-487.

Kincaid, R. L. 2000. Assessment of trace mineral status of ruminants: A review. J. Anim. Sci. 77:1-10.

Kleinschmit, D. H., J. L. Anderson, D. J. Schingoethe, K. F. Kalscheur, and A. R. Hippen. 2007. Ruminal and intestinal degradability of distillers grains plus solubles varies by source. J. Dairy Sci. 90:2909-2918

Kononoff, P. J., A. J. Heinrichs, and D. R. Buckmaster. 2003. Modification of the Penn State forage and total mixed ration particle separator and the effects of moisture content on its measurements. J. Dairy Sci. 86:1858-1863.

Kononoff, P. J., S. K. Ivan, and T. J. Klopfenstein. 2007. Estimation of the proportion of feed protein digested in the small intestine of cattle consuming wet corn gluten feed. J. Dairy Sci. 90:2377-2385.

Kononoff, P. J., S. K. Ivan, W. Matzke, R. J. Grant, R. A. Stock, and T. J. Klopfenstein. 2006. Milk production of dairy cows fed wet corn gluten feed during the dry period and lactation. J. Dairy Sci. 89:2608-2617.

Lock, A. 2010. Update on dietary and management effects on milk fat. Pages 15-26 in Proc. Tri-State Dairy Nutr. Conf., Fort Wayne, IN. The Ohio State University, Columbus.

Lopez, H., F. D. Kanitz, V. R. Moreira, L. D. Satter, and M. C. Wiltbank. 2004. Reproductive performance of dairy cows fed two concentrations of phosphorus. J. Dairy Sci. 87:146-157.

MacLeod, G. K., T. E. Droppo, D. G. Grieve, D. J. Barney, and W. Rafalowski. 1985. Feeding value of wet corn gluten feed for lactating dairy cows. Can. J. Anim. Sci. 65:125-134.

Mahjoubi, E., H. Amanlou, D. Zahmatkesh, M. Ghelich Khan, and N. Aghaziarati. 2009. Use of beet pulp as a replacement for barley grain to manage body condition score in over-conditioned late lactation cows. Anim. Feed Sci. Technol. 153:60-67.

Maia, M. R. G., R. J. B. Bessa, and R. J. Wallace. 2009. Is the trans-10 shift that sometimes occurs in the ruminal biohydrogenation of linoleic acid caused by low pH or starch? A Rusitec study. Pages 276-277 in Ruminant Physiology. Digestion, Metabolism, and Ef- fects of Nutrition on Reproduction and Welfare. Y. Chilliard, F. Glasser, Y. Faulconnier, F. Bocquier, I. Veissier, and M. Doreau, ed. Wageningen Academic Publishers, Wageningen, the Netherlands.

Mansfield, H. R., and M. D. Stern. 1994. Effects of soybean hulls and lignosulfonate-treated soybean meal on ruminal fermentation in lactating dairy cows. J. Dairy Sci. 77:1070-1083.

Mansfield, H. R., M. D. Stern, and D. E. Otterby. 1994. Effects of beet pulp and animal by-products on milk yield and in vitro fermentation by rumen microorganisms. J. Dairy Sci. 77:205-216.

McCandlish, A. C. 1920. The digestibility of sorghum mill refuse. J. Dairy Sci. 3:367-369.

Mertens, D. R. 1997. Creating a system for meeting the fiber requirements of dairy cows. J. Dairy Sci. 80:1463-1481.

Miron, J., E. Yosef, E. Maltz, and I. Halachmi. 2003. Soybean hulls as a replacement of forage neutral detergent fiber in total mixed rations of lactating cows. Anim. Feed Sci. Technol. 106:21-28.

Mjoun, K., K. F. Kalscheur, A. R. Hippen, and D. J. Schingoethe. 2010. Ruminal degradability and intestinal digestibility of protein and amino acids in soybean and corn distillers grains products. J. Dairy Sci. 93:4144-4154.

Morrow, D. A. 1976. Fat cow syndrome. J. Dairy Sci. 59:1625-1629.

Mowrey, A., and J. N. Spain. 1999. Results of a nationwide survey to determine feedstuffs fed to lactating dairy cows. J. Dairy Sci. $82: 445-451$.

Mullins, C. R., K. N. Grigsby, D. E. Anderson, E. C. Titgemeyer, and B. J. Bradford. 2010. Effects of feeding increasing levels of wet corn gluten feed on production and ruminal fermentation in lactating dairy cows. J. Dairy Sci. 93:5329-5337.

Mullins, C. R., D. Weber, E. Block, J. F. Smith, M. J. Brouk, and B. J. Bradford. 2011. Effects of balancing for methionine and lysine in a lactation diet containing high concentrations of wet corn gluten feed. J. Dairy Sci. 94(E-Suppl. 1):489. (Abstr.)

Nakamura, T., T. J. Klopfenstein, and R. A. Britton. 1994. Evaluation of acid detergent insoluble nitrogen as an indicator of protein quality in nonforage proteins. J. Anim. Sci. 72:1043-1048.

Nakamura, T., and F. G. Owen. 1989. High amounts of soyhulls for pelleted concentrate diets. J. Dairy Sci. 72:988-994.

Nichols, J. R., D. J. Schingoethe, H. A. Maiga, M. J. Brouk, and M. S. Piepenbrink. 1998. Evaluation of corn distillers grains and ruminally protected lysine and methionine for lactating dairy cows. J. Dairy Sci. 81:482-491.

NRC. 2001. Nutrient Requirements of Dairy Cattle. 7th rev. ed. Natl. Acad. Sci., Washington, DC.

NRC. 2005. Mineral Tolerance of Animals. 2nd rev. ed. Natl. Acad. Sci., Washington, DC.

Pacheco, D., R. A. Patton, C. Parys, and H. Lapierre. 2012. Ability of commercially available dairy ration programs to predict duodenal flows of protein and essential amino acids in dairy cows. J. Dairy Sci. 95:937-963.

Pantoja, J., J. L. Firkins, M. L. Eastridge, and B. L. Hull. 1994. Effects of fat saturation and source of fiber on site of nutrient digestion and milk production by lactating dairy cows. J. Dairy Sci. 77:2341-2356.

Petersen, W. E. 1932. A formula for evaluating feeds on the basis of digestible nutrients. J. Dairy Sci. 15:293-297.

Pimentel, D. 2003. Ethanol fuels: Energy balance, economics, and environmental impacts are negative. Nat. Resour. Res. 12:127-134.

Rajagopalan, S., E. Ponnampalam, D. McCalla, and M. Stowers. 2005. Enhancing profitability of dry mill ethanol plants. Appl. Biochem. Biotechnol. 120:37-50.

Ranathunga, S. D., K. F. Kalscheur, A. R. Hippen, and D. J. Schingoethe. 2010. Replacement of starch from corn with nonforage fiber from distillers grains and soyhulls in diets of lactating dairy cows. J. Dairy Sci. 93:1086-1097.

Rezac, D. J., K. N. Grigsby, N. M. Bello, and B. J. Bradford. 2012. Effects of varying rates of tallgrass prairie hay and wet corn gluten feed on productivity of lactating dairy cows. J. Dairy Sci. 95:842-849.

Rezac, D. J., K. N. Grigsby, and B. J. Bradford. 2010. Effects of varying rates of tallgrass prairie hay and wet corn gluten feed on pro- 
ductivity of dairy cows. Kansas State University Dairy Research 2010. Accessed Apr. 10, 2012. http://www.ksre.ksu.edu/library/ lvstk2/srp1039.pdf.

Schingoethe, D. J., M. J. Brouk, and C. P. Birkelo. 1999. Milk production and composition from cows fed wet corn distillers grains. J. Dairy Sci. 82:574-580.

Schingoethe, D. J., K. F. Kalscheur, A. R. Hippen, and A. D. Garcia. 2009. Invited review: The use of distillers products in dairy cattle diets. J. Dairy Sci. 92:5802-5813.

Schroeder, J. W. 2010. Corn gluten feed: Composition, storage, handling, feeding and value. North Dakota State University Extension Publication AS-1127.

Spiehs, M. J., and V. H. Varel. 2009. Nutrient excretion and odorant production in manure from cattle fed corn wet distillers grains with solubles. J. Anim. Sci. 87:2977-2984.

Staples, C. R., C. L. Davis, G. C. McCoy, and J. H. Clark. 1984. Feeding value of wet corn gluten feed for lactating dairy cows. J. Dairy Sci. 67:1214-1220.

Stewart, B. A., R. E. James, M. D. Hanigan, and K. F. Knowlton. 2012. Technical Note: Cost of reducing protein and phosphorus content of dairy rations. Prof. Anim. Sci. 28:115-119.

Stock, R. A., J. M. Lewis, T. J. Klopfenstein, and C. T. Milton. 2000. Review of new information on the use of wet and dry milling feed by-products in feedlot diets. J. Anim. Sci. 77(E-Suppl.):1-12.

St-Pierre, N. R. 2005. New version of SESAME. Pages 131-136 in Proc. Tri-State Dairy Nutr. Conf., Ft. Wayne, IN. The Ohio State University, Columbus.

St-Pierre, N. R. 2011. Feed and nutrient costs in dairy production: Where are we now? Buckeye Dairy News. Accessed Apr. 10, 2012. http://dairy.osu.edu/bdnews/Volume\%2013\%20issue\%202\%20 file/Volume\% 2013\%20Issue\%202.html\#Feed.

St-Pierre, N. R., and D. Glamocic. 2000. Estimating unit costs of nutrients from market prices of feedstuffs. J. Dairy Sci. 83:1402-1411.

St-Pierre, N. R., and J. R. Knapp. 2008. Economics of making nutritional decisions with volatile feed prices. Pages 139-149 in Proc. High Plains Dairy Conf., Albuquerque, NM. Kansas State University, Manhattan.

St-Pierre, N. R., and W. P. Weiss. 2006. Managing feedstuff variation in nutritional practice. J. Dairy Sci. 89(Suppl. 1):383. (Abstr.)

Sullivan, M. L., K. N. Grigsby, and B. J. Bradford. 2011. Effects of corn gluten feed and effective NDF on ruminal $\mathrm{pH}$ and productivity of lactating dairy cattle. J. Dairy Sci. 94(E-Suppl. 1):455. (Abstr.)

Swain, S. M., and L. E. Armentano. 1994. Quantitative evaluation of fiber from nonforage sources used to replace alfalfa silage. J. Dairy Sci. 77:2318-2331.
Van Horn, H. H., G. L. Newton, and W. E. Kunkle. 1996. Ruminant nutrition from an environmental perspective: Factors affecting whole-farm nutrient balance. J. Anim. Sci. 74:3082-3102.

VanBaale, M. J., J. E. Shirley, E. C. Titgemeyer, A. F. Park, M. J. Meyer, R. U. Lindquist, and R. T. Ethington. 2001. Evaluation of wet corn gluten feed in diets for lactating dairy cows. J. Dairy Sci. 84:2478-2485.

VandeHaar, M. J. 1998. Efficiency of nutrient use and relationship to profitability on dairy farms. J. Dairy Sci. 81:272-282.

Voelker, J. A., and M. S. Allen. 2003. Pelleted beet pulp substituted for high-moisture corn: 1. Effects on feed intake, chewing behavior, and milk production of lactating dairy cows. J. Dairy Sci. $86: 3542-3552$

Weiss, W. P. 2008. Mineral tolerances of animals. Pages 59-64 in Proc. Tri-State Dairy Nutr. Conf., Ft. Wayne, IN. The Ohio State University, Columbus.

Weiss, W. P. 2012. Use of a corn milling product in diets for dairy cows to alleviate milk fat depression. J. Dairy Sci. 95:2081-2090.

Weiss, W. P., and J. M. Pinos-Rodriguez. 2009. Production responses of dairy cows when fed supplemental fat in low- and high-forage diets. J. Dairy Sci. 92:6144-6155.

World Agricultural Outlook Board. 2012. World Agricultural Supply and Demand Estimates; April 10, 2012. United States Department of Agriculture, Washington, DC.

Yang, W. Z., and K. A. Beauchemin. 2006. Increasing the physically effective fiber content of dairy cow diets may lower efficiency of feed use. J. Dairy Sci. 89:2694-2704

Yang, W. Z., and K. A. Beauchemin. 2007. Altering physically effective fiber intake through forage proportion and particle length: Chewing and ruminal pH. J. Dairy Sci. 90:2826-2838.

Younker, R. S., S. D. Winland, J. L. Firkins, and B. L. Hull. 1998. Effects of replacing forage fiber or nonfiber carbohydrates with dried brewers grains. J. Dairy Sci. 81:2645-2656.

Zebeli, Q.. J. Dijkstra, M. Tafaj, H. Steingass, B. N. Ametaj, and W. Drochner. 2008. Modeling the adequacy of dietary fiber in dairy cows based on the responses of ruminal $\mathrm{pH}$ and milk fat production to composition of the diet. J. Dairy Sci. 91:2046-2066

Zebeli, Q., D. Mansmann, B. N. Ametaj, H. Steingaß, and W. Drochner. 2010. A model to optimise the requirements of lactating dairy cows for physically effective neutral detergent fibre. Arch. Anim. Nutr. 64:265-278. 